JURNAL PUBLIPRENEUR: POLITEKNIK NEGERI MEDIA KREATIF

Vol. 8, No. 2, December 2020, hal. 57-64

Submitted: 5 December 2020

Revised: 15 December 2020

Accepted: 26 December 2020

\title{
THE EFFECT OF e-WOM AND BRAND LOVE ON THE PURCHASING DECISIONS IN ONLINE SHOPPING
}

\author{
Dwi Mandasari Rahayu, M.M \\ Politeknik Negeri Media Kreatif \\ mandasari@polimedia.ac.id
}

\begin{abstract}
The objectives of this research are: to analyze the effect of e-WOM on brand love, to analyze the effect of eWOM on purchasing decisions in online shopping, to analyze the effect of brand love on purchasing decisions in online shopping. This research used quantitative methods, with a total sample of 243 online shopping in the Jabodetabek area. The research used online survey methods in the form of questionnaires. The sampling technique used purposive sampling. The scaling technique of the study applied Likert scale which produces measurements at intervals; scale 1 for strongly disagree statements and scale 5 for strongly agree statements. The data analysis used SEM (Structural Equation Modeling). The findings showed that there is a positive effect of e-WOM variable on brand love variable with a t-count value of 7.01 with an estimate of 0.43 . The eWOM variable has a positive effect on purchase decision with $t$-count value of 7.08 with an estimate of 0.47 . Brand love is the last variable that has a positive effect on purchasing decisions with a $t$-count value of 6.92 with an estimate of 0.35 .
\end{abstract}

Keyword: e-WOM, brand love, and purchase decisions

\section{PENGARUH $e$-WOM DAN BRAND LOVE TERHADAP KEPUTUSAN PEMBELIAN DALAM BELANJA ONLINE}

\begin{abstract}
ABSTRAK
Penelitian yang dilakukan ini bertujuan untuk menganalisis pengaruh $e$-WOM terhadap brand love, menganalisis pengaruh $e-W O M$ terhadap keputusan pembelian dalam belanja online, menganalisis pengaruh brand love terhadap keputusan pembelian dalam belanja online. Penelitian ini menggunakan pendekatan kuantitatif, dengan jumlah sampel sebanyak 243 responden yang pernah melakukan belanja secara online di wilayah Jabodetabek. Pengumpulan data menggunakan kuesioner secara online. Teknik pengambilan sampel menggunakan purposive sampling. Teknik pemberian skala yang digunakan pada penelitian ini yaitu menggunakan skala likert yang menghasilkan pengukuran interval yaitu skala 1 untuk pernyataan sangat tidak setuju dan skala 5 untuk pernyataan sangat setuju. Analisis data yang digunakan menggunakan SEM (Structural Equation Modeling). Berdasarkan hasil penelitian ini maka dapat disimpulkan adanya pengaruh positif antara variabel $e-W O M$ terhadap variabel brand love dengan nilai thitung sebesar 7.01 dengan estimate yaitu 0.43 . Variabel $e-W O M$ memiliki pengaruh positif terhadap keputusan pembelian dengan nilai t-hitung sebesar 7.08 dengan estimate yaitu 0.47. Brand love merupakan variabel terakhir yang memiliki pengaruh positif terhadap keputusan pembelian dengan nilai t-hitung sebesar 6.92 dengan estimate yaitu 0.35 .
\end{abstract}

Kata kunci: e-WOM, brand love, dan keputusan pembelian 
PENDAHULUAN

Perkembangan zaman saat ini yang disebabkan kemajuan teknologi infomasi dan komunikasi mempengaruhi gaya hiup manusia. Jarak, waktu dan lokasi bukan lagi menjadi hambatan dalam proses komunikasi. Keberadaan internet menjadi solusi membuat hal yang sulit menjadi lebih mudah. Banyak hal yang saat ini dapat dilakukan manusia secara cepat, mudah, praktis dan secara online dengan mengoptimalkan keberadaan internet (Kominfo, 2018).

Berdasarkan data Hasil Survey Nasional dari Asosiasi Penyelenggara Internet Indonesia (APJII) Tahun 2018, bahwa pengguna jasa internet Indonesi tahun 2018 mencapai 171,17 juta jiwa setara dengan $64,8 \%$ dari total populasi penduduk Indonesia sebesar 264,16 juta jiwa. Hal ini menjadi peluang besar dalam proses pemasaran barang dan jasa secara online. Berikut ini terlampir data perkembangan penggunaan internet di Indonesia dari tahun 20162018:

Tabel 1

Data Pengguna Intenet di Indonesia Tahun 2016-2018
Dapat dilihat dari tabel di atas, bahwa penggunaan internet di Indonesia dari tahun ke tahun mengalami peningkatan yang sangat pesat. Berdasarkan hasil Survey Asosiasi Penyelenggara Internet Indonesia (APJII) Tahun 2018 bahwa ada 4 konten internet (komersial) yang sering digunakan untuk membeli barang dan jasa secara online diantaranya yaitu ; Shoppe sebesar 11,2\%, Bukalapak sebesar 8,4\%, Lazada sebesar 6,7\%, dan Tokopedia 4,3\%. Proses pemasaran secara online saat ini menjadi pilihan yang tepat bagi para produsen dan konsumen. Berdasarkan Puti dan Fitrah (2017) bahwa pemasaran secara online dapat memanfaatkan internet untuk memberikan infografis tentang produk yang akan dipasarkan suatu perusahaan dengan lebih mengutamakan pada merek sebuah barang atau jasa yang akan dipasarkan.

Ruane dan Wallance (2013) mengatakan bahwa untuk saat ini penggunaan media sosial sebagai alat pemasaran semakin banyak digunakan. Hal ini dilakukan untuk dapat mengelola hubungan dengan para pelanggan. Selain itu penggunaan media sosial yang semakin populer dapat mempengaruhi perilaku orang dalam berbelanja.

Tahun $\begin{gathered}\text { Jumlah } \\ \text { Pengguna }\end{gathered}$

\begin{tabular}{ccc}
\hline 2016 & 132,7 & $52,50 \%$ \\
2017 & 143,26 & $54,68 \%$ \\
2018 & 171,17 & $64,80 \%$ \\
\hline
\end{tabular}

Sumber : Asosiasi Penyelenggara Internet Indonesia (APJII)
Ada beberapa faktor yang mempengaruhi perilaku seseorang dalam berbelanja, salah satunya yaitu WOM. Word of Mouth (WOM) mाerupakan salah satu bentuk pemasaran baru dalam proses komunikasi yaitu dengan memberi rekomendasi secara pribadi kepada individu dan kelompok tentang produk atau layanan yang bertujuan untuk memberikan informasi (Jatmika, 2014). 


\section{JURNAL PUBLIPRENEUR: POLITEKNIK NEGERI MEDIA KREATIF Vol. 8, No. 2, December 2020, hal. 57-64}

Seiring dengan adanya perkembangan teknologi dan komunikasi maka internet serta media sosial dapat mempengaruhi pola operasional pada WOM (Chan dan Ngai, 2011). Menurut Charo,et al (2015) bahwa pola pertukaran informasi dan pengetahuan online di internet dan media sosial dapat dikenal sebagai Electronic Word-ofMouth (e-WOM).

Kecintaan terhadap suatu merek atau dapat disebut brand love menurut Carroll dan Ahuvia (2006) yaitu sikap konsumen yang telah mencapai ketertarikan secara emosi karena merasa puas terhadap suatu produk tertentu. Hal ini akan mempengaruhi konsumen yang telah cinta terhadap suatu merek sehingga akan menimbulkan keinginan yang kuat untuk mengkonsumsi merek tersebut serta tidak ingin berpaling ke merek yang lain. Dengan demikian maka kecintaan terhadap suatu merek akan cenderung mempengaruhi terhadap ke loyalitas konsumen sehingga hal ini dapat menjadi keuntungan bagi perusahaan.

Kotler dan Armstrong menyatakan bahwa bagi konsumen pembelian bukan hanya merupakan tindakan saja, melainkan terdiri atas beberapa tindakan yang saling berkaitan. Dimensi keputusan pembelian terdiri dari pilihan produk, pilihan merek, pilihan saluran pembelian, waktu pembelian, serta jumlah pembelian. Bila konsumen melakukan keputusan untuk melakukan belanja melalui media online. Hal ini merupakan hasil pemikiran yang sudah diputuskan dalam memilih saluran pembelian secara online. Adapun faktor yang mempengaruhinya berdasarkan pelayanan yang diberikan, kemudahan untuk mendapatkan, serta kesediaan barang.

Penelitian yang dilakukan ini memiliki tujuan untuk menganalisis pengaruh $e$ WOM terhadap brand love, menganalisis pengaruh e-WOM terhadap keputusan pembelian dalam belanja online, serta menganalisis pengaruh brand love terhadap keputusan pembelian dalam belanja online.

Penelitian sebelumnya yang dilakukan oleh Laksmi dan Oktavani (2016) yaitu Pengaruh electronic word of mouth (eWOM) terhadap minat membeli follower Instagram pada warunk upnormal. Terdapat pula penelitian yang dilakukan Mughoffar dan Sumarwan (2018) yang membahas eWOM merupakan instrumen untuk membentuk brand image dan minat dalam membeli produk oleh konsumen.

Masalah yang terjadi selama ini orang belum mengetahui secara pasti keterkaitan e-WOM dalam proses belanja online. Padahal manfaat yang dimiliki $e-W O M$ sangat besar terhadap konsumen dalam proses menentukan seseorang jadi atau tidaknya untuk membeli suatu produk. Terdapat komentar ataupun ulasan dari konsumen yang sudah menggunakan produk tersebut. Hal ini menjadi pertimbangan bagi calon konsumen dalam menentukan keputusan pembelian. Berdasarkan hal tersebut maka dilakukanlah peneliti ini. Keunggulan penelitian ini dalam proses belanja online untuk mengetahui 
keterlibatan $e-W O M$ yang saat ini sering digunakan sebagai referensi sebelum melakukan transaksi belanja. Dalam hal ini kita dapat mengetahui dan menganalisis apakah konsep e-WOM akan mempengaruhi brand love serta keputusan pembelian seseorang dalam melakukan belanja online tersebut. Dengan demikian maka dapat dirumuskan pertanyaan penelitian sebagai berikut:

1. Apakah terdapat pengaruh positif e-WOM terhadap brand love?

2. Apakah terdapat pengaruh positif e-WOM terhadap keputusan pembelian?

3. Apakah terdapat pengaruh brand love terhadap keputusan pembelian?

\section{METODE PENELITIAN}

Penelitian menggunakan pendekatan kuantitatif melalui survei menggunakan aplikasi media sosial. Survei dilakukan dengan mendistribusikan kuesioner online. Teknik pengambilan sampel menggunakan purposive sampling yaitu penarikan sample berdasarkan pertimbangan sampel yang dipilih pada karakteristik tertentu (Sekaran, 2006). Karakteristik demografi responden dalam penelitian ini berdasarkan jenis kelamin, domisili, usia, pendidikan, pekerjaan, penghasilan per bulan, serta jumlah belanja online. Populasi dalam penelitian ini yaitu seluruh konsumen yang pernah belanja secara online berlokasi di Jabodetabek (Jakarta, Bogor Depok, Tangerang, dan Bekasi) dengan jumlah sampel sebanyak 243 responden. Analisis data yang digunakan menggunakan SEM (Structural Equation Modeling).
Variabel yang diteliti adalah e-WOM, brand love, dan keputusan pembelian. Teknik penskalaan yang digunakan adalah Skala Likert dengan susunan interval skala 1 sampai dengan skala 5 . Proses pengujian indikator sebagai berikut ; 1) Sangat Tidak Setuju, 2) Tidak Setuju, 3) Netral, 4) Setuju dan 5) Sangat Setuju. Menurut Malhotra (2010) bahwa untuk penelitian yang menggunakan metode analisis regresi dan SEM (Structural Equation Model) yaitu yang memiliki jumlah sampel berkisar antara 200 hingga 400 responden.

Jenis dan sumber data dalam penelitian ini ada dua yaitu data primer diperoleh langsung dengan cara menyebarkan kuesioner secara online yang diisi oleh responden. Terdapat pula data sekunder yang berasal dari buku literatur, jurnal dan artikel yang terkait dengan e-WOM, brand love, dan keputusan pembelian serta informasi pembelian secara online.

Penelitian ini difokuskan pada korelasi e-WOM, brand love, dan keputusan pembelian yang disajikan dalam kerangka penelitian pada Gambar 1 berikut:

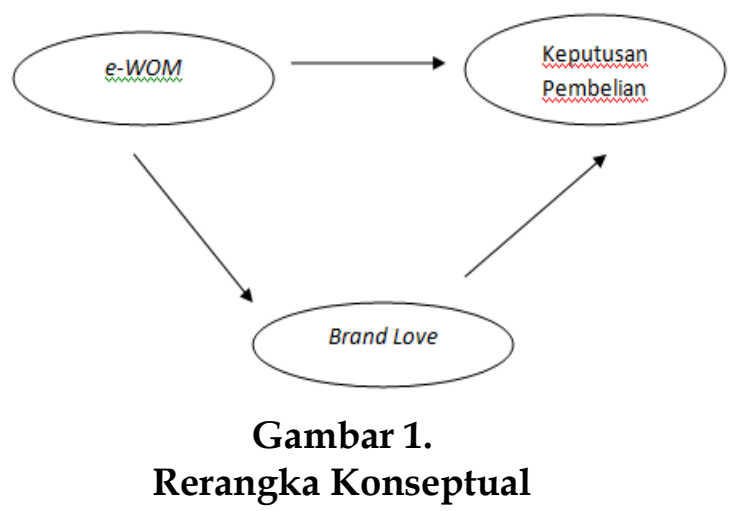


JURNAL PUBLIPRENEUR: POLITEKNIK NEGERI MEDIA KREATIF

Vol. 8, No. 2, December 2020, hal. 57-64

Submitted: 5 December 2020 Revised: 15 December 2020

Accepted: 26 December 2020

\section{HASIL DAN PEMBAHASAN}

Hasil

Responden dalam penelitian ini adalah orang yang pernah melakukan belanja secara online. Karakteristik demografi responden dalam penelitian ini berdasarkan jenis kelamin, domisili, usia, pendidikan, pekerjaan, penghasilan per bulan, serta jumlah belanja secara online. Data Karakteristik Responden disajikan pada Tabel 2.

Tabel 2

Karakteristik Responden

\begin{tabular}{ccc}
$\begin{array}{c}\text { Karakter } \\
\text { Demografi }\end{array}$ & $\begin{array}{c}\text { Jumlah } \\
(\mathrm{n}=243)\end{array}$ & $\begin{array}{c}\text { Persentase } \\
(\%)\end{array}$ \\
\hline
\end{tabular}

\begin{tabular}{lcc}
\hline Gender & & \\
Pria & 98 & $40 \%$ \\
Wanita & 145 & $60 \%$
\end{tabular}

Domisili

Jakarta

Bogor

Bekasi

Tangerang

Depok

Usia

$<20$ thn

21 - 30 thn

$31-40$ thn

41 - 50 thn

$>50$ thn

Pendidikan

SMA/SMK

D3

S1

S2/S3

Pekerjaan

Mahasiswa

PNS/BUMN

Swasta

Wiraswasta
159

17

29

27

11

27

59

$65 \%$

$7 \%$

$12 \%$

$11 \%$

$5 \%$

$11 \%$

$46 \%$

$25 \%$

$12 \%$

$5 \%$

$14 \%$

$18 \%$

$39 \%$

$30 \%$

72

46

35

134

28
Penghasilan perbln

$\begin{array}{lll}<1 \text { juta } & 26 & 11 \% \\ 1 \text { juta- } 3 \text { juta } & 43 & 18 \% \\ 3 \text { juta- } 5 \text { juta } & 81 & 33 \% \\ 5 \text { juta- }-10 \text { juta } & 62 & 26 \% \\ >\text { 20juta } & 31 & 13 \%\end{array}$

Belanja online

$0-1$ / bln $\quad 34 \quad 14 \%$

$2-4 /$ bln $\quad 76 \quad 31 \%$

$1-2 /$ minggu $\quad 81 \quad 33 \%$

3-4/minggu $\quad 47 \quad 19 \%$

setiap hari

5

$2 \%$

Sumber : Hasil data

Berdasarkan karakteristik responden pada table 2 dapat kita simpulkan bahwa jumlah responden yang paling banyak melakukan belanja online yaitu wanita sebanyak 145 orang $(60 \%)$ yang berdomisili di DKI Jakarta sebanyak 159 orang (65\%). Responden terbanyak memiliki usia antara 21-30 tahun sebanyak 112 orang (46\%). Tingkat pendidikan responden terbanyak yaitu Sarjana S1 terdapat 94 orang (39\%). Jenis pekerjaan terbanyak yang melakukan belanja online pada Pegawai Swasta yaitu 134 orang (55\%) dengan rata-rata pendapatan perbulan Rp. 3.000.000 - Rp. 5.000 .000 sebanyak 81 orang (33\%). Intensitas atau jumlah belanja online yang paling banyak dilakukan 12/minggu yaitu 81 orang (33\%).

Pengujian model pengukuran dilakukan untuk menentukan validitas dan reliabilitas model pengukuran yang akan digunakan dalam penelitian. Uji Validitas untuk mengetahui item yang $19 \%$ terdapat pada pernyataan dalam $14 \%$ penelitian yang digunakan untuk $55 \%$ mengukur variable tersebut adalah $12 \%$ valid. Pengukuran model validitas yang 
digunakan adalah uji-t menggunakan software MS Excel dilakukan dengan cara yang mudah. Penelitian ini dinyatakan valid apabila nilai $t>1,96$.

Uji Reabilitas merupakan konsistensi dari serangkaian pengukuran. Sebuah instrument kuisioner dikatakan reliabel jika pernyataan tersebut konsisten, stabil dari waktu ke waktu. Menurut Sekaran (2006) menyatakan bahwa dasar pengambilan keputusan uji reabilitas jika koefisien cronbach's alpha $\geq 0.6$ maka cronbach's alpha acceptable (constract reliable). Data Pengujian Model Validitas dan Reliabilitas akan disajikan pada table 3 .

\begin{tabular}{|c|c|c|c|c|c|}
\hline \multirow[b]{2}{*}{ Variabel } & \multicolumn{4}{|c|}{ Tabel 3} & \multirow[b]{2}{*}{ Ket } \\
\hline & Indikator & $\begin{array}{l}\text { Nilai t- } \\
\text { hitung }\end{array}$ & Ket & $\begin{array}{c}\text { Cronbach } \\
\text { Alpha }\end{array}$ & \\
\hline \multirow[t]{4}{*}{$e-W O M$} & MS 1 & 11.13 & Valid & 0.812 & Reliabel \\
\hline & MS 2 & 13.22 & Valid & 0.947 & Reliabel \\
\hline & MS 3 & 12.47 & Valid & 0.857 & Reliabel \\
\hline & MS 4 & 11.46 & Valid & 0.823 & Reliabel \\
\hline \multirow[t]{4}{*}{ Brand Love } & BA 1 & 12.87 & Valid & 0.864 & Reliabel \\
\hline & BA 2 & 9.43 & Valid & 0.784 & Reliabel \\
\hline & BA 3 & 13.51 & Valid & 0.963 & Reliabel \\
\hline & BA 4 & 11.68 & Valid & 0.835 & Reliabel \\
\hline \multirow[t]{4}{*}{$\begin{array}{l}\text { Keputusan } \\
\text { Pembelian }\end{array}$} & BL 1 & 12.43 & Valid & 0852 & Reliabel \\
\hline & BL 2 & 13.12 & Valid & 0.928 & Reliabel \\
\hline & BL 3 & 10.28 & Valid & 0.793 & Reliabel \\
\hline & BL 4 & 11.67 & Valid & 0.832 & Reliabel \\
\hline
\end{tabular}

Hasil dari pengujian setiap indikator pada setiap variabel yang disajikan menunjukkan bahwa semua indikator variabel adalah valid karena nilai $t$ hitung masing-masing indikator di atas 1,96. Dan nilai koefisien cronbach's alpha $\geq 0.6$ sehingga dapat dikatakan reliabel. Dengan demikian dapat disimpulkan bahwa keseluruhan data dapat digunakan, sehingga temuan penelitian dapat dianggap valid dan reliabel.

Tabel 4 Hasil Uji Regresi

Hipotesis Var $\quad$ Est. t-hit Ket

\begin{tabular}{|c|c|c|c|c|}
\hline H1 & $\begin{array}{c}\text { e-WOM } \rightarrow \\
\text { Brand } \\
\text { Love }\end{array}$ & 0.43 & 7.01 & $\begin{array}{c}\mathrm{H} 1 \\
\text { diterima }\end{array}$ \\
\hline $\mathrm{H} 2$ & $\begin{array}{l}\text { e-WOM } \rightarrow \\
\text { Keputusan } \\
\text { Pembelian }\end{array}$ & 0.47 & 7.08 & $\begin{array}{c}\mathrm{H} 2 \\
\text { diterima }\end{array}$ \\
\hline H3 & $\begin{array}{c}\text { Brand } \\
\text { Love } \rightarrow \\
\text { Keputusan } \\
\text { Pembelian }\end{array}$ & 0.35 & 6.92 & $\begin{array}{c}\mathrm{H} 3 \\
\text { diterima }\end{array}$ \\
\hline
\end{tabular}

\section{Pembahasan}

Hasil pengujian hipotesis dapat dilihat pada Tabel 4. Menurut Gozali (2008) bahwa tingkat signifikan masingmasing korelasi antar variabel dapat dilihat dari nilai t-hitung yang harus lebih besar dari t-tabel (t-hitung $>1.96$ ) untuk efek signifikansi.

H1 menyatakan bahwa e-WOM memiliki pengaruh positif terhadap brand love sehingga dapat dikatakan $e$ WOM memiliki pengaruh yang signifikan terhadap brand love dengan nilai t-hitung sebesar 7.01 dengan estimate yaitu 0.43 . Nilai estimate 0.43 menunjukkan bahwa e-WOM memberikan pengaruh yang cukup besar terhadap brand love. Dengan demikian dapat disimpulkan bahwa hipotesis 1 diterima. Hal ini menunjukkan bahwa komentar, pendapat serta saran yang biasa terdapat pada media sosial memiliki pengaruh yang besar terhadap suatu brand. Ketika seorang konsumen ingin melakukan belanja secara online maka sering melihat pendapat/ulasan terkait brand tersebut dari masyarakat yang lebih dahulu menggunakannya. Semakin baik kesan masyarakat terhadap suatu brand yang terdapat pada e-WOM maka akan meningkatkan 


\section{JURNAL PUBLIPRENEUR: POLITEKNIK NEGERI MEDIA KREATIF Vol. 8, No. 2, December 2020, hal. 57-64}

Submitted: 5 December 2020

Revised: 15 December 2020

Accepted: 26 December 2020

kecintaan terhadap brand tersebut (brand love).

H2 menyatakan bahwa e-WOM memiliki pengaruh positif terhadap keputusan pembelian sehingga dapat dikatakan e-WOM memiliki pengaruh yang signifikan terhadap keputusan pembelian dengan nilai t-hitung sebesar 7.08 dengan estimate yaitu 0.47 . Nilai estimate 0.47 menunjukkan bahwa $e$ WOM memberikan pengaruh yang cukup besar terhadap keputusan pembelian. Dengan demikian dapat disimpulkan bahwa hipotesis 2 diterima. Hal ini menunjukkan komentar, pendapat ataupun ulasan konsumen di media sosial akan mempengaruhi keputusan pembelian seseorang untuk melakukan belanja secara online. Berdasarkan penelitian yang sudah dilakukan oleh Laksmi dan Oktavani (2016) bahwa e-WOM berpengaruh langsung terhadap minat beli seseorang. Terbukti dari hasil penelitian menunjukkan bahwa e-WOM dan minat beli saling mempengaruhi satu dengan yang lain. Hal ini sesuai dengan penelitian yang telah dilakukan oleh Jimenez dan Mendoza (2013) dengan hasil yang menunjukkan bahwa $e-W O M$ memiliki pengaruh terhadap perilaku konsumen sebelum konsumen memutuskan untuk membeli suatu barang atau jasa.

H3 yang menyatakan bahwa brand love memiliki pengaruh positif terhadap keputusan pembelian sehingga dapat dikatakan brand love memiliki pengaruh yang signifikan terhadap keputusan pembelian dengan nilai t-hitung sebesar 6.92 dengan estimate yaitu 0.35 . Nilai estimate 0.35 menunjukkan bahwa brand love memberikan pengaruh yang cukup besar terhadap keputusan pembelian. Dengan demikian dapat disimpulkan bahwa hipotesis 3 diterima. Hal ini menunjukkan bahwa ketika seorang konsumen sudah memiliki kecintaan terhadap suatu merek (brand love) hal ini sangat mempengaruhi konsumen tersebut untuk dapat melakukan keputusan pembelian terhadap brand tersebut. Hasil penelitian ini sejalan dengan penelitian yang telah dilakukan oleh Naufal \& Maftukhah (2017) pada pengguna kamera digital Canon di Semarang yang memperoleh hasil penelitian yaitu brand love berpengaruh positif dan signifikan terhadap purchase decision.

\section{KESIMPULAN}

Berdasarkan hasil penelitian ini maka dapat disimpulkan bahwa:

1. Pengaruh positif $e-W O M$ terhadap brand love dengan nilai t-hitung sebesar 7.01 dengan estimate yaitu 0.43. Hal ini menunjukkan keberadaan komentar atau review terhadap penggunaan produk di media sosial memiliki manfaat yang besar sehingga dapat meningkatkan rasa cinta terhadap suatu merek produk.

2. Pengaruh positif $e-W O M$ terhadap keputusan pembelian dengan nilai thitung sebesar 7.08 dengan estimate yaitu 0.47. Hal ini menunjukkan bahwa ulasan suatu produk yang baik di media sosial akan menimbulkan ketertarikan seseorang untuk mencoba produk tersebut, sehingga akan mempengaruhi keputusan 
pembelian konsumen terhadap suatu produk.

3. Pengaruh positif brand love terhadap keputusan pembelian dengan nilai thitung sebesar 6.92 dengan estimate yaitu 0.35. Hal ini menunjukkan bahwa ketika konsumen sudah menyukai/mencintai merek tertentu maka akan mempengaruhi dalam proses pemilihan produk. Keputusan pembelian terhadap merek produk berdasarkan merek produk yang disukai.

Adapun saran yang dapat dilakukan untuk melanjutkan penelitian berikutnya yaitu dapat melakukan penambahan variable brand image, brand loyalty, dan brand trust serta perlu memperluas sampel dan objek penelitian untuk memperoleh hasil penelitian yang lebih generalisasi.

\section{DAFTAR PUSTAKA}

Asosiasi Penyelenggaran Jasa Internet Indonesia. (2018). Penetrasi $\mathcal{E}$ Prilaku Pengguna Internet Indonesia . APJII.

Carroll ; Ahuvia. (2006). Some antecedents and outcomes of brand love. Marketing Letters, 79-89.

Chan, Y., \& Ngai, E. (2011). Conceptualizing electronic word of mouth activity. Marketing Intelligence and Planning 29, 488-516.

Gozali, I. (2008). SEM Metode Alternatif dengan PLS. Semarang : Badan Penerbit Universitas Diponogoro.

Jatmika, C. (2014). Pengaruh electronic word of mouth terhadap brand image $\mathcal{E}$ purchase intention smartphone samsung di Surabaya. Calypta:
Jurnal Ilmiah Mahasiswa Universitas Surabaya , 1-15.

Kotler, P., \& Armstrong, G. (2012). Principles of Marketing 14th ed. Upper Saddle River, N.J.: Pearson Prentice Hall.

Laksmi, A., \& Oktafani, F. (2016). Pengaruh electronic word of mouth (eWOM) terhadap minat membeli follower pada Instagram. Jurnal Computech \& Bisnis 11, 1-12.

Malhotra, \& Naresh, K. (2010). Riset Pemasaran (Marketing Research) Edisi 4 Jilid 1. Indonesia: PT. Indeks.

Mughoffar, \& Sumarwan. (2018). The Effect Of e-WOM and Brand Image on The Interest in Buying The Heavenly Blush Yoghurt Product. Indonesian Journal of Business and Entrepreneurship, Vol. 5 No. 2.

Naufal, M. H., \& I, M. (2017). Pengaruh Brand Image dan Brand Love terhadap Purchase Decision melalui Word of Mouth. Management Analysis Journal, 377-387.

Putri, S. D., \& Fithrah, D. S. (2017). Pengaruh Online Marketing Campaign\#samyangchallenge Terhadap Consumer Behavior Digital. Jurnal Profesi Humas, 132-141.

Ruane, L., \& Wallace, E. (2013). Generation $Y$ females online: insights from brand narratives. Qualitative Market Research: An International Journal, 315-335.

Sekaran. (2006). Research Methods For Business (Metode Penelitian untuk Bisnis) Edisi empat buku 1. Salemba Empat. 